Bluetongue virus genetic and phenotypic diversity: towards identifying the molecular determinants that influence virulence and transmission potential

Peter Coetzee ${ }^{1,3 \S}$, Moritz Van Vuuren $^{1}$, Maria Stokstad ${ }^{3}$, Mette Myrmel $^{2}$, Estelle. H. Venter ${ }^{1}$

${ }^{1}$ Department of Veterinary Tropical Diseases, Faculty of Veterinary Science, University of Pretoria, Private Bag X04, Onderstepoort, Pretoria, 0110, South Africa

${ }^{2}$ Department of Food Safety and Infection Biology, Norwegian School of Veterinary Science, P. O. Box 8146, Oslo, Norway

${ }^{3}$ Department of Production Animal Clinical Sciences, Norwegian School of Veterinary Science, P. O. Box 8146, Department 0033, Oslo, Norway

${ }^{\S}$ Corresponding author

Email addresses:

EHV: estelle.venter@up.ac.za

MM: mette.myrmel@nvh.no

MS: maria.stokstad@nvh.no

MvV: moritz.vanvuuren@up.ac.za

P: peter.coetzee@yahoo.com 


\section{Bluetongue virus genetic and phenotypic diversity: towards identifying the molecular determinants that influence virulence and transmission potential}

\section{Abstract}

Bluetongue virus (BTV) is the prototype member of the Orbivirus genus in the family Reoviridae and is the aetiological agent of the arthropod transmitted disease bluetongue (BT) that affects both ruminant and camelid species. The disease is of significant global importance due to its economic impact and effect on animal welfare. Bluetongue virus, a dsRNA virus, evolves through a process of quasispecies evolution that is driven by genetic drift and shift as well as intragenic recombination. Quasispecies evolution coupled with founder effect and evolutionary selective pressures has over time led to the establishment of genetically distinct strains of the virus in different epidemiological systems throughout the world.

Bluetongue virus field strains may differ substantially from each other with regards to their phenotypic properties (i.e. virulence and/or transmission potential). The intrinsic molecular determinants that influence the phenotype of BTV have not yet clearly been characterized. It is currently unclear what contribution each of the viral genome segments have in determining the phenotypic properties of the virus and it is also unknown how genetic variability in the individual viral genes and their functional domains relate to differences in phenotype.

In order to understand how genetic variation in particular viral genes could potentially influence the phenotypic properties of the virus; a closer understanding of the BTV virion, its 
encoded proteins and the evolutionary mechanisms that shape the diversity of the virus is required. This review provides a synopsis of these issues and highlights some of the studies that have been conducted on BTV and the closely related African horse sickness virus (AHSV) that have contributed to ongoing attempts to identify the molecular determinants that influence the virus' phenotype. Different strategies that can be used to generate BTV mutants in vitro and methods through which the causality between particular genetic modifications and changes in phenotype may be determined are also described. Finally examples are highlighted where a clear understanding of the molecular determinants that influence the phenotype of the virus may have contributed to risk assessment and mitigation strategies during recent outbreaks of BT in Europe.

\section{Keywords}

Bluetongue virus, bluetongue, genetic drift, genetic shift, intragenic recombination, phenotype, virulence, transmission potential, reverse genetics, modified-live virus vaccine strain.

\section{General introduction}

Bluetongue virus (BTV) is the type species of the genus Orbivirus in the family Reoviridae (Borden et al., 1971) and causes an infectious, non-contagious, arthropod transmitted disease of ruminants and camelids called bluetongue (BT) (Spreull, 1905). Twenty six distinct serotypes of the virus have been identified to date (Chaignat et al., 2009; Howell et al., 1970; Maan et al., 2011). Bluetongue virus is transmitted primarily by biting midges that belong to the Culicoides genus (Diptera: Ceratopogonidae) (Du Toit, 1944). The distribution of the virus closely matches the distribution of vector-competent midge species and climatic conditions that support a large 
population of these insects. The virus therefore occurs more commonly in tropical and subtropical regions of the world between the latitudes of $40-50{ }^{\circ} \mathrm{N}$ and $35^{\circ} \mathrm{S}$ and during times of the year that are optimal for vector activity (Gibbs and Greiner, 1994; Mellor et al., 2000).

Bluetongue virus infection in ruminants is characterized by damage to endothelial cells lining small caliber blood vessels resulting in vascular thrombosis, ischaemic necrosis, haemorrhage and vascular leakage (Erasmus, 1975a; Mahrt and Osburn, 1986). Clinical signs of BT in sheep may include any combination of fever, depression, anorexia, nasal discharge, facial and pulmonary oedema, coronitis, erosions of the mucosa of the buccal cavity, occasional cyanosis of the tongue and muscle degeneration (Maclachlan et al., 2008; Spreull, 1905). Bluetongue virus causes severe disease in certain breeds of sheep (especially European fine wool and mutton breeds) (Spreull, 1905) and certain species of deer (Vosdingh et al., 1968), whereas cattle and goats are usually sub-clinically affected (Anderson et al., 1985; Luedke and Anakwenze, 1972). The mortality of the disease amongst susceptible sheep can range from 2$30 \%$ during mild outbreaks (Verwoerd et al., 2004), but can occasionally be as high as 70\% (Gambles, 1949).

In endemic regions local ruminant breeds demonstrate resistance against the disease. Overt clinical signs are therefore usually only observed when susceptible breeds are imported into BT endemic regions or when the virus is introduced into immunologically naïve flocks in regions where it is not normally encountered (Gibbs and Greiner, 1994). The clinical presentation of BT also varies even amongst susceptible sheep, ranging from sub-clinical to acute disease that can lead to the death of infected animals. This variation in severity is influenced both by intrinsic 
differences in virulence between infecting field strains as well as extrinsic host, vector and environmental factors (breed, age, nutritional status, level of immunity, inoculum titre, temperature, UV radiation (Erasmus, 1975a).

\section{Genetic and phenotypic diversity}

Bluetongue virus circulates in different regions of the world in distinct ecological zones or that are defined by the occurrence of particular Culicoides populations (Tabachnick, 2004). The localized circulation of the virus in these host-vector defined 'episystems' has over time led to the evolution of distinct geographical strains or topotypes of the virus. These viruses are broadly divided into western and eastern lineages and further regional subtypes based on phylogenetic analysis of sequence data of the majority of viral genome segments (Gould, 1987; Gould and Pritchard, 1990; Maan et al., 2010). The virus also demonstrates substantial genetic variation even amongst strains that circulate in the same geographical region. For example it has been demonstrated that the nucleotide sequence of the NS3/A encoding gene of BTV field isolates collected from pools of $C$. sonorenis from a single dairy in California in the United States, varied over a three month period from 97.54 to $100 \%$ nucleotide sequence identity (Bonneau et al., 2002).

Genetically heterogeneous BTV field strains may vary substantially from each other with regards to their phenotypic properties (i.e. virulence and transmission potential). For example, differences have been noted to exist in the virulence of BTV-4 from South Africa and BTV-4 that circulates in the Americas (South America, Central America, and Caribbean). Bluetongue virus serotype 4 from South Africa is highly virulent when inoculated experimentally into Merino 
sheep (Maclachlan et al., 2008), whereas BTV-4 that circulates in the Americas appears to be less virulent and is rarely associated with clinical disease in the field (Gibbs and Greiner, 1994). In addition it has been documented that certain strains of BTV in South Africa are more often isolated from Culicoides and are therefore thought to have a high transmission potential, whereas others are more often isolated from acutely affected sheep and appear to have a high pathogenic index (Anonymous, 1985; Nevill et al., 1992). Differences have also been reported to exist in virulence between Australian and South African strains of BTV, with Australian strains generally being considered to be less virulent than strains from South Africa (Kirkland, 2004).

Modified-live virus vaccine strains have been attenuated from wild type strains in South Africa and the United States by sequentially passaging field isolates in embryonated chicken eggs and cell culture. The sequential passage of BTV in these atypical host systems results in the attenuation of virulent field strains, presumably by selecting for quasispecies variants that have a reduced ability to infect and replicate in the ruminant host (Erasmus, 1975b; Walton, 1992). Differences in BTV phenotype are also emphasized when comparing modified-live virus vaccine strains (MLV) to wild type strains. Apart from a decrease in virulence, MLV strains differ from wild type strains in that they demonstrate novel biological properties. These include an increased tendency to cross the ruminant placenta when used in pregnant females resulting in infection of the foetus (Flanagan and Johnson, 1995; Schultz and Delay, 1955) as well as a possible increased tendency to be secreted in the semen of older rams and bulls (Kirkland and Hawkes, 2004). Modified-live virus vaccine strains may also possibly have an increased ability to infect and replicate in Culicoides. For example, studies on the closely related AHSV indicated that when an AHSV-7 MLV strain and corresponding field isolates of the same serotype were 
evaluated in an oral susceptibility study in C. imicola and C. bolitinos in South Africa, recovery rates and viral titres of the vaccine strain were higher after the extrinsic incubation period had been completed than for wild type strains (Venter and Paweska, 2007)..

\section{Structural and molecular biology of BTV}

Bluetongue virus has a segmented genome that consists of 10 linear double stranded RNA segments (dsRNA) (Verwoerd et al., 1970). The 10 viral genome segments encode seven structural (VP1-VP7) and five non-structural proteins (NS1, NS2, NS3, NS3A, NS4) (Ratinier et al., 2011; van Dijk and Huismans, 1988). Each of the genome segments except segments 9 and 10 codes for a single protein. Segment 9 codes for both VP6 and non-structural protein 4 (NS4), with the latter being translated from an overlapping reading frame (Firth, 2008; Ratinier et al., 2011). Similarly segment 10 codes for two proteins, with translation of NS3/A, a truncated version of full length NS3 lacking the N-terminal 13 amino acid residues, being initiated from an internal in-frame methionine codon (van Dijk and Huismans, 1988).

Viral proteins VP1 to VP7 constitute the structural components of the mature BTV virion, whereas the non-structural proteins (NS1-NS4) are only found in BTV infected cells (Ratinier et al., 2011; van Dijk and Huismans, 1988). The mature BTV virion is non-enveloped, spherical in appearance and can be divided into an outer diffuse protein layer, a transcriptionally active core and an icosahedral sub-core. The sub-core is composed of 60 dimers of VP3 (coded for by segment 3) that are arranged with icosahedral symmetry. The sub-core is covered by 260 trimers of VP7 (coded for by segment 7) that curve around the surface of the sub-core (Grimes et al., 1998; Hewat et al., 1992; Huismans et al., 1987; Verwoerd et al., 1972). Epitopes of VP7 
are exposed through the outer protein layer of the BTV virion (Lewis and Grubman, 1990) and mediate the attachment and infection of insect cells (Tan et al., 2001; Xu et al., 1997). The outer diffuse protein layer of the mature virion is composed of 60 VP2 trimers (coded for by segment 2) that are interspersed with 120 VP5 trimers (coded for by segment 6) (Hewat et al., 1992). Viral protein 2 functions as the mammalian cell receptor ligand and contains the epitopes that determine virus serotype (Hassan and Roy, 1999; Huismans and Erasmus, 1981; Kahlon et al., 1983; Mertens et al., 1989). Viral protein 5 functions as the viral fusion protein and facilitates the penetration of viral cores into the cytoplasm of mammalian cells during receptor-mediated endocytosis (Forzan et al., 2007; Forzan et al., 2004; Hassan et al., 2001; Zhang et al., 2010). The protein also appears to play a minor role in influencing BTV serotype, possibly through stearic interaction with VP2 at the virion surface (Cowley and Gorman, 1989; Mertens et al., 1989).

Viral transcription is facilitated by ten transcriptase complexes that are situated on the inner side of the sub-core, below pores that are present at the $5^{\prime}$ fold axis of the VP3 icosahedron (Nason et al., 2004). The transcriptase complexes are composed of three minor structural proteins that include VP1 (coded for by segment 1 ) that functions as the viral RNA-dependant RNA polymerase (Boyce et al., 2004; Urakawa et al., 1989), VP4 (coded for by segment 4) that caps and methylates newly synthesized mRNA strands (Martinez-Costas et al., 1998; Ramadevi et al., 1998) and VP6 that unwinds and re-anneals the dsRNA genome during transcription (Stauber et al., 1997).

Non-structural protein 1 (coded for by segment 5) forms characteristic tubular structures in the 
cytoplasm of infected mammalian and insect cells. The exact role that these structures play in the replication cycle of the virus has not been determined (Huismans and Els, 1979; Owens et al., 2004; Urakawa and Roy, 1988). It has however been proposed that NS1 may play a role in the morphogenesis of BTV and the intracellular trafficking of the virus to the plasma membrane (Eaton et al., 1988). There is also evidence to suggest that NS1 may influence the pathogenesis of BTV infection in the vertebrate host. The interruption of NS1 tubule formation through the expression of anti-NS1 antibody Fc fragments in mammalian cell culture for example has been shown to convert viral release from a lytic infection to non-cytopathic budding and resulted in a significant increase in the amount of virus that was released from infected cells (Owens et al., 2004).

Viral assembly is facilitated by the NS2 phosphoprotein (coded for by segment 8 ) that rapidly accumulates as viral inclusion bodies (VIBs) in the cytoplasm of infected cells (Brookes et al., 1993; Modrof et al., 2005).It has been demonstrated by immuno-staining that VIBs in addition to NS2 also contains the other structural proteins that are required for core assembly (Brookes et al., 1993). The protein is also able to bind to single stranded RNA (ssRNA) and is thought to mediate the assortment of the correct genome segments into progeny viral pre-cursor particles. This process may be mediated by the specific recognition of secondary ssRNA structures by the protein (Lymperopoulos et al., 2006).

The intracellular trafficking and release of BTV from infected cells is mediated by the viral glycoprotein NS3 (coded for by segment 10) and its alternative form NS3/A. The NS3/A proteins are integral membrane proteins that are over expressed in insect cells relative to mammalian 
cells (Bansal et al., 1998; Guirakhoo et al., 1995). The proteins are associated with smooth intracellular vesicles as well as the plasma membrane (Wu et al., 1992) and co-localizes at sites of viral release at the cell surface (Hyatt et al., 1991). Cell lysis with an associated cytopathic effect is mainly observed in mammalian cells, whereas budding of virions without cell death occurs in insect cells (Han and Harty, 2004; Hyatt et al., 1993). Cell lysis is likely mediated by two viroporin-like hydrophobic domains that are able to interact with the mammalian cell membrane to induce membrane pore formation (Han and Harty, 2004). The budding of progeny virus particles in contrast appears to be facilitated through the simultaneous interaction of VP2 and NS3/A with components of the host cell export machinery. The N-terminal domain of the NS3/A protein has been demonstrated to be able to interact with the calcipitin light chain (p11) of the cellular annexin II complex that is involved in cellular exocytosis (Beaton et al., 2002) as well as Tsg101 a cellular protein that has been implicated in the intracellular trafficking and release of a number of enveloped viruses (Wirblich et al., 2006) The C-terminal domain of the protein in contrast is able to bind to VP2 on the surface of mature virus particles, suggesting that the NS3/A protein is able to act as a bridge between the virus and the cellular export machinery (Beaton et al., 2002). Studies with mutants, obtained by reverse genetics that express either full length NS3 or NS3A has demonstrated that whereas NS3/A is dispensable for viral release in mammalian cells, both NS3 and NS3/A appear to be required for efficient viral release in insect cells (Celma and Roy, 2011).

The non-structural protein (NS4) has only recently been discovered and only cursory studies have been conducted to elucidate its function in the viral replication cycle. Non-structural protein NS4 appears to localize in the nucleolus of infected cells early during the viral 
replication cycle and contains "coiled-coil" domains that are similar to nucleic acid binding proteins (Belhouchet et al., 2011; Ratinier et al., 2011). Nucleic acid protection assays have demonstrated that NS4 is able to bind to double stranded DNA (Belhouchet et al., 2011) and it has been suggested that the protein may be involved in subverting host cell antiviral defences, possibly by modulating the transcription of genes in the nucleolus (Ratinier et al., 2011). Indeed it has been demonstrated that NS4 is able to confer a replication advantage to wild type BTV-8 in infected mammalian cells that are in an interferon induced anti-viral state in contrast to a BTV-8 mutant lacking the ability to express the protein (Ratinier et al., 2011).

\section{Bluetongue virus evolution}

Bluetongue virus evolves through a combination of genetic drift/shift as well as intragenic recombination (Bonneau et al., 2001; He et al., 2010; Samal et al., 1987a; Samal et al., 1987b; Stott et al., 1987). These evolutionary processes result in the generation of quasispecies populations in the host or vector, from which variants with optimal fitness may be selected under different environmental conditions. Quasispecies evolution together with the random fixation of quasispecies variants during the transmission of the virus between its vertebrate and invertebrate host, appear to be the main mechanisms leading to the observed genetic diversity amongst BTV field strains (Balasuriya et al., 2008; Bonneau and Maclachlan, 2004; Bonneau et al., 2001).

RNA viruses lack a proofreading function in their RNA dependant RNA polymerases and are therefore characterized by an error prone replication process and high mutation rates (Bonneat et al., 2001). In silico analysis of segments 2, 3, 6 and 10 of time stratified nucleotide sequences 
of a worldwide panel of BTV isolates has shown that the evolutionary rate in these segments vary from between 0.52 to $6.0 \times 10^{-4}$ nucleotide substitutions per site/per year (Carpi et al., 2010). The occurrence of genetic drift has experimentally been confirmed for BTV during the transmission of the virus between its invertebrate and vertebrate host. The sequential transmission of plaque purified BTV-10 between sheep, cattle and $C$. sonorensis midges and the genetic characterization of viral genes (VP2 and NS3 encoding genome segments) of quasispecies variants, indicated that whereas the BTV-10 consensus sequence remained largely conserved, viral replication in each host also resulted in the establishment of an unique set of minor quasispecies variants. It was furthermore also demonstrated that minor variants may be randomly fixed from a quasispecies population by founder effect (genetic bottleneck). One group of $C$. sonorensis that were fed on an infected sheep demonstrated the fixation of a minor variant from the quasispecies population present in the blood of the infected animal (Bonneau et al., 2001).

Genetic reassortment (genetic shift) has long been implicated as a mechanism that can generate genetic diversity amongst RNA viruses with segmented genomes and has been demonstrated for different RNA virus families including Reoviridae (Wenske et al., 1985) e.g. Rotavirus (Kirkwood, 2010) and Bunyaviridae (Bishop and Beaty, 1988) amongst others. The segmented nature of the BTV genome allows the virus to freely exchange its genome segments between different co-infecting strains in concurrently infected host cells. The opportunity for BTV to reassort in nature is emphasized through the observation that concurrent infections with more than one strain of ruminants in the field has frequently been demonstrated (Brenner et al., 2010; Stott et al., 1982; Stott et al., 1985). Evidence for the occurrence of BTV genetic 
reassortment has also been obtained though oligonucleotide fingerprint analysis (Sugiyama et al., 1982) as well as hybridization (de Mattos et al., 1991) and molecular sequencing studies (Batten et al., 2008; de Mattos et al., 1996; Maan et al., 2012a; Maan et al., 2012b; Maan et al., 2010; Mecham and Johnson, 2005; Pierce et al., 1998; White et al., 2006) on BTV field isolates.

The kinetics of BTV genetic reassortment has further been investigated experimentally in sheep (Samal et al., 1987b), bovine (Oberst et al., 1987) and C. variipennis (El Hussein et al., 1989; Samal et al., 1987a) as well as in cell culture (Ramig et al., 1989). These studies have indicated that reassortment occurs at varying frequencies in the different host systems. In sheep, the fraction of reassortant progeny clones recovered from viraemic animals was approximately $5 \%$ (Samal et al., 1987b), whereas in a similar study in bovine the ratio of recovered reassortant progeny was significantly higher (89\%) (Stott et al., 1987). A high fraction of reassortants have also been recovered from mixed infected Culicoides midges $(7-78 \%$ of clones recovered per infected midge). The high proportion of reassortants that have been recovered from concurrently infected midges suggests that the insects are highly permissive hosts for the reassortment of the virus in nature (Samal et al., 1987a). This is especially significant when one considers that Culicoides are infected with the virus for the duration of their adult life span and that adult female Culicoides may take multiple blood meals (Mellor et al., 2000). The frequency of reassortment in infected African Green Monkey Kidney (Vero) cells has also been shown to be high, with $54 \%$ of recovered progeny virions being reassortants (Ramig et al., 1989).

With regards to the type of reassortants that were isolated from different host systems, typically one of the parental strains dominated the yield of recovered virions with the other 
parental strain only being represented by its contribution of genome segments to the reassortant progeny. Multiple unique reassortant strains were further isolated from each of the host systems, with some strains dominating the yield of the recovered reassortant progeny later during infection. This suggests that these viruses had either reassorted their genome segments earlier during the infection cycle and had therefore replicated to a higher titre or that the viruses had acquired genome segments that conferred a selective growth advantage over the other reassortant progeny. Indeed reassortment appears to occur non-randomly for some of the genome segments (e.g. 5, 7, 8, 9 and 10) (El Hussein et al., 1989; Ramig et al., 1989; Samal et al., 1987a; Samal et al., 1987b). The exact advantages that are conferred on the reassortant progeny by the selection for or against these genome segments are however unknown.

The asynchronous infection of Culicoides as well as vertebrate cell culture with two or more strains of BTV has also shown that cells that have been infected with a particular strain become increasingly resistant against infection with a secondary strain at increasing time intervals post infection, a phenomena that is called "viral exclusion". Although the exact mechanism of viral exclusion has not been determined, it is thought to limit the frequency with which reassortment occurs in the vertebrate host and insect vector to times when these hosts are infected simultaneously with more than one strain of the virus, or nearly so (El Hussein et al., 1989; Ramig et al., 1989).

The exact molecular mechanism that facilitates BTV genetic reassortment has not been determined. It has been suggested that reassortment may be facilitated by the selection of viral 
ssRNA by VIBs (NS2) during the packaging of the viral genome segments into sub-core particles (Gould and Hyatt, 1994). The NS2 protein rapidly forms as a matrix around individual transcribing viral cores in the cytoplasm of infected cells. Smaller VIBs eventually fuse to form large cellular inclusion bodies (Fu, 1995), thereby creating the ideal situation for reassortment to occur by bringing genome segments from different virus strains into close association.

Intragenic recombination whereby mosaic genes are generated from the "splicing" together of homologous genes from different ancestral viral strains has recently been demonstrated for BTV. Analysis of 690 complete BTV gene sequences available on Genbank, representing all of the genome segments of the virus has indicated that up to $1.6 \%$ of the analyzed sequences represented unique recombination events (He et al., 2010). Recombination was found to have occurred in all of the viral genome segments except segments 5 and 6, with recombinants having undergone either single, double or multiple cross-over events. Interestingly it was found that several BTV strains isolated at different time points and from different geographical locations contained genome segments that appeared to be descended from common mosaic ancestors indicating that recombinant genes had become fixed amongst dominant strains in the field. This observation suggests (but does not prove) that the acquisition of the recombinant genes by these dominant field strains may have resulted in an increased evolutionary fitness of these viruses in the field (He et al., 2010).

The exact mechanism through which BTV recombination occurs is currently unclear. He et al., (2010) suggested that recombination may be facilitated by regions within the viral genome that are prone to the formation of RNA secondary structures. These regions could allow parenteral 
RNA segments from disparate origins to interact with each other, thereby allowing recombination to occur. In the study by He et al., (2010) secondary RNA structure prediction indicated that the regions around the breaking points of all mosaic sequences demonstrated the potential for RNA secondary structures to form (He et al., 2010).

\section{Potential molecular determinants that may influence the phenotype of BTV}

The nucleotide sequences of the genome segments of BTV display varying degrees of conservation that reflect both the error prone replication process and the selective pressures that act on the encoded proteins (Balasuriya et al., 2008; Bonneau and Maclachlan, 2004; Bonneau et al., 2001). In general the genes encoding the proteins of the BTV sub-core (segments 1, 3, 4 and 9) and non-structural proteins (segments 8 and 9) are conserved, due to either functional or structural constraints that act to limit the evolution of the encoded proteins. In contrast, the outer capsid proteins (VP2 and VP5) are exposed to external selective pressures such as the ruminant immune system and the encoding genes are therefore more variable (Maan et al., 2008; Maan et al., 2007a). Viral protein 7 is relatively conserved within the BTV serogroup, however the encoding gene also demonstrates sequence diversity that clusters the virus into several clades, the biological relevance of which is currently unknown (Bonneau et al., 2000; Wilson et al., 2000). Similarly the NS3/A encoding gene demonstrates significant nucleotide sequence variability when compared to the segments that encode the other non-structural proteins (Balasuriya et al., 2008).

When considering variation in phenotype between BTV strains, differences in virulence or transmission potential are likely attributable to genetic variation within the more variable 
genome segments (those encoding VP2, VP5, VP7 and NS3/A). This hypothesis is supported by several studies on BTV and the closely related AHSV that have highlighted the role that changes in these proteins may have on the phenotypic properties of the virus.

Initial evidence for the involvement of the outer capsid proteins in influencing virulence was obtained from cross-hybridization studies that indicated that the proteins undergo changes during attenuation of the virus in cell culture (Huismans \& Howell, 1973). The role of VP2 in determining BTV virulence was subsequently investigated in several studies using virulent and non-virulent field strains that indicated that the attenuation of virulent strains may be related to amino acid changes in the VP2 protein that abrogates the ability of the virus to be neutralized by monoclonal antibodies (Bernard et al., 1996; Bernard et al., 1994; Gould and Eaton, 1990; Wilson et al., 2008). Changes in VP2 may however not singly be responsible for differences in the neutralization characteristics of BTV, as it has been demonstrated that amino acid changes in VP5 (without accompanying changes in VP2) may also lead to the development of neutralization resistance (DeMaula et al., 2000).

The role of VP5 in determining the virulence of BTV is supported through the study of two naturally occurring reassortants of BTV-11 named UC-2 and UC-8 that were isolated from the field in the USA. The two viral strains shared the same VP2 segments, but differed with regards to their VP5 segments. The UC2 strain derived its genome segment 5 from a BTV-11 modifiedlive virus vaccine (MLV) strain, whereas UC-8 derived its segment 5 from a BTV-10 MLV vaccine strain (de Mattos et al., 1991; Osburn, 1994). When inoculated into new-born mice, UC-2 was found to be virulent only when inoculated via the intra-cranial route, whereas UC- 8 was 
virulent when inoculated via either the sub-cutaneous or intra-cranial route (Waldvogel et al., 1987; Waldvogel et al., 1986). The two viral strains also differed with regards to their ability to cause disease in foetal calves, depending on the gestational age at which the foetus was infected. When foetuses were inoculated through the uterine wall at 120 days of gestation, both strains were able to cause neurological abnormalities (Waldvogel et al., 1992b). In contrast, the inoculation of foetuses with UC-2 at 243 days of gestation led to the birth of healthy calves, while inoculation with UC-8 led to the premature birth of small and weak calves that displayed mild encephalitis (Waldvogel et al., 1992a). The underlying molecular basis for the enhanced virulence of UC-8 relative to UC- 2 is not known. It has been suggested that it may be related to stearic interaction between the different versions of VP2 and VP5 at the virion surface that could potentially affect both viral binding as well as neutralization (Carr et al., 1994).

The precise molecular mechanism that leads to the attenuation of wild type strains following sequential passage in embryonated chicken and cell culture has not been clearly characterized.

A study was conducted in order to further investigate the viral genes and amino acid substitutions that are involved in the attenuation of BTV field strains during the virus's passage in atypical host systems (Caporale et al., 2011a). In this study the authors compared the virulence of both low and high cell culture passage BTV strains from Italy and South Africa by infecting 3-day old NIH-Swiss and adult interferon receptor deficient mice. In general the low passage field strains demonstrated a virulent phenotype in the murine models, whereas high passage strains were non-virulent. Sequence analysis of the VP1, VP2 and NS2 encoding genome segments demonstrated consistent non-synonymous amino acid changes between low 
and high passage virus strains, suggesting that one or more of these proteins may be involved in modulating virulence (Caporale et al., 2011a).

Variation in the NS3/A protein may also potentially influence the severity of BTV infection in the mammalian host as the protein causes cell membrane damage and thus has a significant role in inducing viral cytopathic effect (Han and Harty, 2004). Indeed it has been demonstrated that variability in the NS3/A gene of the closely related African horse sickness virus (AHSV) is associated with differences in cellular cytopathogenecity. The AHSV NS3/A protein in contrast to BTV is highly diverse ( $37 \%$ amino acid sequence variability) and clusters into three phylogenetic clades $(\alpha, \beta$ and $\gamma$ ) with virus strains belonging to each of these clades differing with regards to the degree with which they are able to induce viral cytopathic effect. The generation of reassortants between parental viruses containing NS3/A genes from each of these clades has shown that the reassortment of NS3/A can significantly alter the cytopathogenecity of reassortant progeny. In this case the extent of these changes was dependant on the type of NS3/A encoding gene that was donated by a particular parental strain (Meiring et al., 2009).

The association of the AHSV NS3/A encoding gene with virulence has been further investigated in the vertebrate host by O'Hara et al., (1998). The authors generated reassortant viruses between a virulent AHSV-3 and a non-virulent AHSV-8 strain dual infection of BHK-21 cells. This yielded two reassortant AHSV-8 viruses that differed with regards to only their NS3/A genome segments. The two reassortant viruses designated as AHSV-A79 and AHSV-A790 contained the NS3/A genes from the avirulent AHSV-8 and virulent AHSV-3 strains respectively and 
demonstrated an avirulent and intermediate virulent phenotype in newborn mice. Therefore the genetic variant of the NS3/A encoding gene from the virulent AHSV-3 was able to confer a novel virulence phenotype to non-virulent AHSV-8 (O'Hara et al., 1998). Cumulatively these studies suggest that AHSV virulence resides with the NS3/A encoding genome segment. It is therefore interesting to speculate that the NS3/A encoding gene of BTV may similarly play a role in modulating virulence.

Infection and the transmission of BTV by Culicoides are influenced by a combination of midge, environmental and virus-specific factors. These factors include amongst others the presence of heritable barriers that prevent the dissemination of the virus in the insect (Fu et al., 1999) and ambient temperature that influences the rate of virogenesis and length of the extrinsic incubation period (Wittmann et al., 2002). With regards to intrinsic virus specific factors that may influence infection and transmission, the VP7 and NS3/A proteins of BTV play an important role in mediating the infection and dissemination of the virus in the insect vector. It has therefore been considered that genetic variation in these proteins may relate to the transmission of the virus by different midge populations in different geographic locations (Bonneau et al., 2000; Maan et al., 2008; Maan et al., 2010; Wilson et al., 2000). The VP7 encoding gene can be divided into several different clades by phylogenetic analysis, however only a weak correlation between these clades and particular geographic locations and/or Culicoides populations have been established (Bonneau et al., 2000; Wilson et al., 2000). Similarly analysis of the amino acid sequence of the NS3/A gene of a global panel of BTV isolates failed to demonstrate adaptive (positive) selection that may be indicative of the coevolution of this protein with particular Culicoides (Balasuriya et al., 2008). 
Despite evidence of a lack of co-evolution of BTV NS3/A with particular Culicoides, one study with AHSV has suggested that the protein may be involved in modulating transmission potential. In this study the effect of variation in the NS3/A gene of reassortant AHSV-A79 and AHSV-A790 (O'Hara et al., 1998) to influence infection and dissemination of the virus in Culicoides was investigated (Riegler, 2002). Results from the study indicated that Culicoides that had been fed on the two reassortant viruses demonstrated differences in both total as well as disseminated infection rates. Overall the results suggested that the two genetic versions of the NS3/A protein either affected the ability of the virus to establish a localized midgut infection or the dissemination of the virus to the insect salivary glands (Riegler, 2002).

Finally bluetongue virus field strains may potentially differ in their infectivity for particular Culicoides based on the amino acid sequence of VP2. It has previously been demonstrated that the cleavage of the virus outer capsid protein VP2 with chemotrypsin and N-lauroyl sarcosinate results in the generation of infectious sub-viral particles (ISVPs) with an enhanced infectivity for Culicoides cells (Mertens et al., 1996). It has recently been demonstrated that a protease in the saliva of Culicoides is similarly able to cleave VP2, resulting in the generation of ISVPs. The protease differed in its ability to cleave the VP2 protein of viruses from either eastern or western origins. Interestingly it was also demonstrated that the amount of the protease differed in the saliva of $C$. sonorenis and $C$. nubeculosus midges, a vector competent and noncompetent species respectively(Darpel et al., 2011).

\section{Towards identifying the molecular determinants that influence BTV phenotype}


The characterization of the genetic differences that exist between phenotypically distinct BTV field strains requires high quality sequence data of the whole viral genome. Whole genome amplification strategies that allow the entire BTV genome to be amplified to a high concentration (required for sequencing) in a single reaction tube, as well as the development of high throughout put sequencing technologies have been established (Maan et al., 2007b; Potgieter et al., 2002). Sequence data of the entire BTV genome can now directly be obtained from blood or tissue samples, without prior virus isolation (Potgieter et al., 2002).

Recently a reverse genetics system for BTV was demonstrated through which infectious virus is entirely recoverable by transfecting cells with in vitro transcribed ssRNA of each of the viral genome segments (Boyce et al., 2008). This method allows individual viral genome segments to be modified by site directed mutagenesis prior to transfection in order to introduce defined mutations into any region of the viral genome. Genome segments from different parenteral viral strains may also be transfected in different combinations in order to yield defined reassortant genotypes (van Gennip et al., 2012; van Gennip et al., 2010). By using these methods it has become possible to generate "tailor-made" BTV mutants with a defined genetic background. Such viruses have become important tools for the study of the effect of mutation or reassortment in conferring a particular phenotype to the virus.

Several in vivo and in vitro approaches may prove useful for comparing the effect of mutation on BTV phenotype. In order to evaluate differences in virulence between BTV strains, experimental transmission studies with BTV in ruminants have frequently been used. It is for example common practice to evaluate the degree of attenuation of MLV strains by comparing 
disease-specific parameters (temperature, length of viraemia and severity of oral lesions) in vaccinated and unvaccinated animals following virus challenge (OIE, 2004). Transmission studies in live animals have obvious disadvantages for ethical, animal welfare and economic reasons; however transmission studies in ruminants are also subjected to several other disadvantages. The clinical signs of BT may be highly variable between different host species and individual animals (Verwoerd and Erasmus, 2004). Due to this variability, a comparison of virulence between BTV strains by using clinical reaction indexes or by comparing pathological features may not give an accurate reflection of strain-specific differences. Furthermore these studies are expensive to conduct and require the use of a large number of animals as well as specialized vector-free facilities.

The use of small animal models provides a suitable alternative for comparing differences in BTV virulence. It has been demonstrated by immunoperoxidase staining that 11-day old chicken embryos show a similar tissue tropism for AHSV as infected horses (Maartens, 2010). Similarly type 1 interferon receptor deficient mice are highly susceptible to BTV infection via both the oral and intravenous route and demonstrate similar clinical and pathological features as the ruminant host (Calvo-Pinilla et al., 2010; Calvo-Pinilla et al., 2009; Caporale et al., 2011b). The use of in vitro methods to compare BTV phenotype also shows promise. The cultivation of primary lung micro-vascular and pulmonary artery endothelial cells from sheep and cattle has made it possible to compare some of the cellular and immunological features that may be responsible for differences in the clinical presentation of BTV in these host species (DeMaula et al., 2001; DeMaula et al., 2002a; DeMaula et al., 2002b). Changes in trans-endothelial cell monolayer electrical resistance (TER) have furthermore been used to provide a quantitative 
measurement of the degree of cell monolayer destruction following BTV infection (Drew et al., 2010). It can be envisaged that these parameters may be compared in permissive cell lines that have been infected with different BTV strains in order to illustrate strain specific differences in BTV phenotype.

Culicoides infection models are used for a comparison of differences in transmission potential. Resistance to BTV oral infection appears to be under control of a single genetic locus (Tabachnick, 1991) and progressive inbreeding of C. sonorensis midges under laboratory conditions has led to the establishment of susceptible midge colonies that are useful for oral susceptibility studies (Jones and Foster, 1974). The maintaining and feeding of Culicoides in the laboratory is well established; however in practice the establishment of laboratory colonies from field caught insects has proven to be an arduous and difficult task. Due to these difficulties only a few species have successfully been colonised (Veronesi et al., 2009). Nevertheless the use of either field caught insects or laboratory colonies have proven invaluable in the investigation of the parameters that influence the transmission of the virus.

Studies on BTV transmission potential are based on the oral infection of Culicoides by using blood meals that are spiked with a defined titre of virus, prior to a comparison of either total or disseminated infection rates after the extrinsic incubation has been completed (Carpenter et al., 2006; Venter et al., 2006; Venter et al., 1998). This provides information on the rate with which different midge species or population can be infected with a particular BTV strain and can also give an indication as to how successfully the virus can be transmitted during subsequent biting activity. In the latter case an individual insect's ability to transmit the virus 
can be evaluated by demonstrating infection of the insect salivary glands by using either immunohistochemical staining, virus isolation or PCR on the head section of the insect. Alternatively it has been suggested that certain threshold titres of virus in infected midges are indicative of vector competence ( $>2.9 \log _{10} \mathrm{TCID}_{50} /$ midge) (Baylis et al., 2008). In the latter case it should be emphasized that the relationship between the virus load and the efficiency with which the virus is transmitted is still unclear (Carpenter et al., 2008). Other potential pitfalls of oral susceptibility studies in Culicoides include difficulties in standardizing the titre of virus in the blood meal prior to blood feeding (Venter et al., 2006), the generally low oral susceptibility of Culicoides for BTV (Bellis et al., 1994; Gerry et al., 2001), as well as the potential varying oral susceptibility of field caught Culicoides based on their geographic origin (Carpenter et al., 2006; Jones and Foster, 1978; Venter and Paweska, 2007).

\section{Why is it important to identify the molecular determinants that influence BTV phenotype?}

The ability to discriminate virulent from non-virulent field strains and to identify viruses with the potential for rapid spread and overwintering represents critical information for informing policy makers with regards to the impact that new outbreaks of the disease are likely to have and for conducting cost-risk analysis prior to the implementation of control measures. This can clearly be demonstrated by the 2006-2008 BTV-8 outbreak in northern Europe (Maan et al., 2008) and the 2008 detection of a BTV-6 MLV vaccine strain reassortant in the eastern Netherlands and later adjacent parts of Germany (Eschbaumer et al., 2009; Maan et al., 2010; van Rijn et al., 2012). 
The 2006-2008 outbreak of BTV-8 in northern Europe represented an unprecedented step change in the epidemiology of the virus. This was the first time that BTV had been encountered in northern Europe in a region that was traditionally thought to be beyond the northern most limits where climatic conditions could sustain a bluetongue epidemic (Purse et al., 2005). Several features of the BTV-8 outbreak made it unusual when compared to outbreaks of BT that occur in other regions of the world. The BTV-8 strain was highly virulent and caused acute disease not only in sheep, but also in cattle and goats (Backx et al., 2007; Darpel et al., 2007). The BTV-8 strain also demonstrated the ability to cross the ruminant placenta a (Backx et al., 2009; Darpel et al., 2009; De Clerq et al., 2008; Desmecht et al., 2008; Menzies et al., 2008; Saegerman et al., 2010; van der Sluijs et al., 2011; Vercauteren et al., 2008), a property that had previously only generally been associated with the vaccination of pregnant animals with MLV strains (Flanagan and Johnson, 1995; Parsonson et al., 1987; Schultz and Delay, 1955).. The BTV-8 strain also appears to have had an increased tendency to be secreted in the semen of infected rams and bulls. Two studies have demonstrated the presence of the BTV-8 RNA and/or infectious virus in the semen of naturally infected bulls and rams by using PCR and/or virus isolation (Leemans et al., 2011; Vanbinst et al., 2010). In one of the studies $75-100 \%$ of semen samples collected from rams between 25-116 days post observation of clinical signs still tested positive for the virus by PCR (Leemans et al., 2011). Finally the BTV-8 strain was spread by indigenous northern European Culicoides species (particularly C. obsoletus and C. pullicaris) that have not previously been implicated in the widespread transmission of the virus (Meiswinkel et al., 2008). 
With regards to the European outbreak of BTV-8, the number field cases was only reduced in Europe in 2008 following widespread vaccination using inactivated vaccines that had only become available that year. The development, testing and authorization of BTV-8 inactivated vaccines were initially delayed in Europe due to uncertainty that existed on the part of pharmaceutical companies with regards to the use of BTV-8 inactivated vaccines in the field (Wilson and Mellor , 2009). In this case knowledge on the genetic determinants that influence BTV virulence could have justified the earlier development and use of inactivated vaccines in order to reduce ruminant mortality. Secondly, European Union member countries still allowed the importation of seropositive pregnant ruminants during the vector free seasons of 20062007 before it became clear that the virus was able to cross the ruminant placenta. This approach failed when it was demonstrated that BTV- 8 seropositive but PCR negative heifers imported into Northern Ireland from the Netherlands gave birth to either PCR positive and/or viraemic offspring (Menzies et al., 2008). This highlighted the possibility of introducing the virus into BTV free countries by using established import/export procedures. Detailed knowledge of the molecular determinants that allow the virus to cross the placenta (such as the genetic markers that affect cell tropism) may have allowed for a timely change in import/export policy before the opportunity had arisen for human assisted dissemination of the virus. In this case a detailed investigation of the genetic changes that leads to an increase in the ability of MLV vaccine strains to cross the placenta as compared to wild type strain may have been informative. Finally a clear understanding of the molecular determinants that influence the efficiency of the transmission of the virus by Culicoides may have emphasised the potential for the rapid spread of the virus as was observed during its re-emergence in 2007. 
In 2008 the circulation of a BTV-6 MLV strain was detected for the first time in north-western Europe in the eastern Netherlands and later in adjacent parts of Germany (Eschbaumer et al., 2009; Maan et al., 2010; van Rijn et al., 2012). Whole genome sequencing confirmed that the majority of genome segments of this strain were closely related to the South African BTV-6 MLV strain, however the analysis also revealed that the virus had received its segment 10 (NS3/A) from a South African BTV-2 MLV strain (Maan et al., 2010). Although it has been established from field observations and experimental transmission studies in sheep and cattle that the strain was relatively avirulent (Eschbaumer et al., 2009; van Rijn et al., 2012), during its initial emergence it was unknown whether the virus would have any significant animal health or economic impact and whether the virus would demonstrate the capability to overwinter. It is frequently highlighted in the literature that genetic reassortment between distinct BTV strains may result in the generation of viruses that demonstrate unique biological properties (Batten et al., 2008; Brenner et al., 2011; Maan et al., 2010; Saegerman et al., 2008; Veronesi et al., 2005). The risk that genetic reassortment poses with regards to the alteration of viral phenotype has however not thoroughly been investigated, with only a few studies available that have directly addressed the issue for BTV. When a wild type-vaccine reassortant BTV emerges in the field such as occurred in northern Europe, it thus initially remains an open question as to whether the virus will demonstrate unique properties. In this case a clear understanding of the determinants influencing the phenotype of BTV may have been useful for predicting the threat that the reassortant may have posed to the European livestock industry. 


\section{Competing interests}

The author(s) declare that they have no competing interests.

\section{Acknowledgements and funding}

The authors gratefully acknowledge the Norwegian School of Veterinary Science (NVH) for funding support.

\section{References}

Anderson, G. A., Stott, J. L., Gershwin, L. J. \& Osburn, B. I., 1985. Subclinical and clinical bluetongue disease in cattle: clinical, pathological and pathogenic considerations. Prog. Clin. Biol. Res. 178, 103-107.

Anonymous, 1985. Biennial Report of the VRIO: Vaccine improvement: 1984-1985.

Backx, A., Heutink, C. G., Van Rooij, E. M. \& Van Rijn, P. A., 2007. Clinical signs of bluetongue virus serotype 8 infection in sheep and goats. Vet. Rec. 161, 591592.

Backx, A., Heutink, R., Van Rooij, E. M. A. \& Van Rijn, P. A., 2009. Transplacental and oral transmission of wild-type bluetongue virus serotype 8 in cattle after experimental infection. Vet. Microbiol. 138, 235-243.

Balasuriya, U. B., Nadler, S. A., Wilson, W. C., Pritchard, L. I., Smythe, A. B., Savini, G., Monaco, F., De, S. P., Zhang, N., Tabachnick, W. J. \& Maclachlan, N. J., 2008. The NS3 proteins of global strains of bluetongue virus evolve into regional topotypes through negative (purifying) selection. Vet. Microbiol. 126, 91-100.

Bansal, O. B., Stokes, A., Bansal, A., Bishop, D. \& Roy, P., 1998. Membrane organization of bluetongue virus nonstructural glycoprotein NS3. J. Virol. 72, 3362-3369.

Batten, C. A., Maan, S., Shaw, A. E., Maan, N. S. \& Mertens, P. P., 2008. A European field strain of bluetongue virus derived from two parental vaccine strains by genome segment reassortment. Virus Res. 137, 56-63.

Baylis, M., O'Connell, L. \& Mellor, P. S., 2008. Rates of bluetongue virus transmission between Culicoides sonorensis and sheep. Med. Vet. Entomol. 22, 228-237. 
Beaton, A. R., Rodriguez, J., Reddy, Y. K. \& Roy, P., 2002. The membrane trafficking protein calpactin forms a complex with bluetongue virus protein NS3 and mediates virus release. Proc. Natl. Acad. Sci. U. S. A. 99, 13154-13159.

Belhouchet, M., Mohd, J. F., Firth, A. E., Grimes, J. M., Mertens, P. P. \& Attoui, H., 2011. Detection of a fourth orbivirus non-structural protein. PLoS One. 6, e25697.

Bellis, G. A., Gibson, D. S., Polkinghorne, I. G., Johnson, S. J. \& Flanagan, M., 1994. Infection of Culicoides brevitarsis and C. wadai (Diptera: Ceratopogonidae) with four Australian serotypes of bluetongue virus. J. Med. Entomol. 31, 382-387.

Bernard, K. A., Israel, B. A. \& Schultz, K. T., 1996. A complex neutralization domain of bluetongue virus serotype 17 defines a virulence-associated marker. Viral Immunol. 9, 97-106.

Bernard, K. A., Israel, B. A., Thompson, L. H., Homan, E. J. \& Schultz, K. T., 1994. Virulence-associated antigenic and genetic characteristics of bluetongue virus-17 isolates. Virology 201, 321-329.

Bishop, D. H. \& Beaty, B.J., 1988. Molecular and biochemical studies of the evolution, infection and transmission of insect bunyaviruses. Philos. T Roy Soc B 321, 463483.

Bonneau, K. R. \& Maclachlan, N. J., 2004. Genetic diversification of field strains of bluetongue virus. Vet. Ital. 40, 446-447.

Bonneau, K. R., Mullens, B. A. \& Maclachlan, N. J., 2001. Occurrence of genetic drift and founder effect during quasispecies evolution of the VP2 and NS3/NS3A genes of bluetongue virus upon passage between sheep, cattle, and Culicoides sonorensis. J. Virol. 75, 8298-8305.

Bonneau, K. R., Topol, J. B., Gerry, A. C., Mullens, B. A., Velten, R. K. \& Maclachlan, N. J., 2002. Variation in the NS3/NS3A gene of bluetongue viruses contained in Culicoides sonorensis collected from a single site in southern California. Virus Res. 84, 59-65.

Bonneau, K. R., Zhang, N. Z., Wilson, W. C., Zhu, J. B., Zhang, F. Q., Li, Z. H., Zhang, K. L., Xiao, L., Xiang, W. B. \& MacLchlan, N. J., 2000. Phylogenetic analysis of the $\mathrm{S} 7$ gene does not segregate Chinese strains of bluetongue virus into a single topotype. Arch. Virol. 145, 1163-1171.

Borden, E. C., Shoorijeh, S. J. \& Murphy, F. A., 1971. Physiochemical and morphological relationships of some athropod-borne viruses to bluetongue virus a new taxonomic group. Physiochemical and serological studies. J. Gen. Virol. 13, 261-271. 
Boyce, M., Celma, C. C. \& Roy, P., 2008. Development of reverse genetics systems for bluetongue virus: recovery of infectious virus from synthetic RNA transcripts. J. Virol. 82, 8339-8348.

Boyce, M., Wehrfritz, J., Noad, R. \& Roy, P., 2004. Purified recombinant bluetongue virus VP1 exhibits RNA replicase activity. J. Virol. 78, 3994-4002.

Brenner, J., Batten, C., Yadin, H., Bumbarov, V., Friedgut, O., Rotenberg, D., Golender, N. \& Oura, C.A., 2011. Clinical syndromes associated with the circulation of multiple serotypes of bluetongue virus in dairy cattle in Israel. Vet Rec. 169, 389.

Brenner, J., Oura, C., Asis, I., Maan, S., Elad, D., Maan, N., Friedgut, O., Nomikou, K., Rotenberg, D., Bumbarov, V., Mertens, P., Yadin, H. \& Batten, C., 2010. Multiple serotypes of bluetongue virus in sheep and cattle, Israel. Emerg Infect Dis. 16, 2003-2004.

Brookes, S. M., Hyatt, A. D. \& Eaton, B. T., 1993. Characterization of virus inclusion bodies in bluetongue virus-infected cells. J. Gen. Virol. 74, 525-530.

Calvo-Pinilla, E., Nieto, J. M. \& Ortego, J., 2010. Experimental oral infection of bluetongue virus serotype 8 in type I interferon receptor-deficient mice. J. Gen. Virol. 91, 2821-2825.

Calvo-Pinilla, E., Rodriguez-Calvo, T., Anguita, J., Sevilla, N. \& Ortego, J., 2009. Establishment of a bluetongue virus infection model in mice that are deficient in the alpha/beta interferon receptor. PLoS. One. 4, e5171.

Caporale, M., Wash, R., Pini, A., Savini, G., Franchi, P., Golder, M., Patterson-Kane, J., Mertens, P., Di Gialleonardo, L., Armillotta, G., Lelli, R., Kellam, P. \& Palmarini, M., 2011a. Determinants of bluetongue virus virulence in murine models of disease. J. Virol. 85, 11479-11489.

Caporale, M., Wash, R., Pini, A., Savini, G., Franchi, P., Golder, M., Patterson-Kane, J., Mertens, P., Di Gialleonardo. L., Armillotta, G., Lelli, R., Kellam, P. \& Palmarini, M., 2011b. Determinants of bluetongue virus virulence in murine models of disease. J. Virol. 85, 11479-11489.

Carpenter, S., Lunt, H. L., Arav, D., Venter, G. J. \& Mellor, P. S., 2006. Oral susceptibility to bluetongue virus of Culicoides (Diptera: Ceratopogonidae) from the United Kingdom. J. Med. Entomol. 43, 73-78.

Carpenter, S., McArthur, C., Selby, R., Ward, R., Nolan, D. V., Luntz, A. J., Dallas, J. F., Tripet, F. \& Mellor, P. S., 2008. Experimental infection studies of UK Culicoides species midges with bluetongue virus serotypes 8 and 9. Vet. Rec. 163, 589-592. 
Carpi, G., Holmes, E. C. \& Kitchen, A., 2010. The evolutionary dynamics of bluetongue virus. J. Mol. Evol. 70, 583-592.

Carr, M. A., de Mattos, C. C., de Mattos, C. A. \& Osburn, B. I., 1994. Association of bluetongue virus gene segment 5 with neuroinvasiveness. J. Virol. 68, 12551257.

Celma, C. C. \& Roy, P., 2011. Interaction of calpactin light chain (S100A10/p11) and a viral NS protein is essential for intracellular trafficking of nonenveloped bluetongue virus. J Virol 85, 4783-4791.

Chaignat, V., Worwa, G., Scherrer, N., Hilbe, M., Ehrensperger, F., Batten, C., Cortyen, M., Hofmann, M. \& Thuer, B., 2009. Toggenburg Orbivirus, a new bluetongue virus: initial detection, first observations in field and experimental infection of goats and sheep. Vet. Microbiol. 138, 11-19.

Cowley, J. A. \& Gorman, B. M., 1989. Cross-neutralization of genetic reassortants of bluetongue virus serotypes 20 and 21. Vet. Microbiol. 19, 37-51.

Darpel, K., Batten, C. A., Veronesi, E., Williamson, S., Anderson, P., Dennison, M., Clifford, S., Smith, C., Phillips, L., Bidewell, C., Bachanek-Bankowska, K., Sanders, A., Wilson, A. J., Gubbins, S., Mertens, P. P. C., Oura, C. A. \& Mellor, P. S., 2009. Transplacental Transmission of Bluetongue Virus 8 in Cattle, UK. Emerg. Infect. Dis. 15, 2025-2028.

Darpel, K. E., Batten, C. A., Veronesi, E., Shaw, A. E., Anthony, S., BachanekBankowska, K., Kgosana, L., Bin-Tarif, A., Carpenter, S., Muller-Doblies, U. U., Takamatsu, H. H., Mellor, P. S., Mertens, P. P. \& Oura, C. A., 2007. Clinical signs and pathology shown by British sheep and cattle infected with bluetongue virus serotype 8 derived from the 2006 outbreak in northern Europe. Vet. Rec. $161,253-261$.

Darpel, K. E., Langner, K. F., Nimtz, M., Anthony, S. J., Brownlie, J., Takamatsu, H. H., Mellor, P. S. \& Mertens, P. P., 2011. Saliva proteins of vector Culicoides modify structure and infectivity of bluetongue virus particles. PLoS One. 6, e17545.

De Clercq, K., Vandenbussche , F., Vandemeulebroucke, E., Vanbinst, T., De Leeuw, I., Verheyden , B., Goris, N., Mintiens, K., Meroc, E., Herr, C., Hooybergs, J., Houdart, P., Sustronck, B., De Deken, G., Maquet, G., Bughin, J., Saulmont, M., Lebrun, M., Bertels, G. \& Miry, C., 2008. Transplacental bluetongue infection in cattle. Vet. Rec. April 26, 2008, 564.

De Clerq, K., Vandenbussche, F., Vandemeulebroucke, E., Vanbinst, T., De Leeuw, I., Verheyden, B., Goris, N., Mintiens, K., Meroc, E., Hooyberghs, J., Houdart, P., Sustronck, B., De Deken, G., Maquet, G., Bughin, J., Saulmont, M., Lebrun, M., 
Bertels, G. \& Miry, C., 2008. Transplacental bluetongue infection in cattle. Vet. Rec. 162, 564.

De Mattos, C. C., de Mattos, C. A., Maclachlan, N. J., Giavedoni, L. D., Yilma, T. \& Osburn, B. I., 1996. Phylogenetic comparison of the S3 gene of United States prototype strains of bluetongue virus with that of field isolates from California. $J$. Virol. 70, 5735-5739.

De Mattos, C.C., de Mattos, C. A., Osburn, B. I., lanconescu, M. \& Kaufman, R., 1991. Evidence of genome segment 5 reassortment in bluetongue virus field isolates. Am. J. Vet. Res. 52, 1794-1798.

DeMaula, C. D., Bonneau, K. R. \& Maclachlan, N. J., 2000. Changes in the outer capsid proteins of bluetongue virus serotype ten that abrogate neutralization by monoclonal antibodies. Virus Res. 67, 59-66.

DeMaula, C. D., Jutila, M. A., Wilson, D. W. \& Maclachlan, N. J., 2001. Infection kinetics, prostacyclin release and cytokine-mediated modulation of the mechanism of cell death during bluetongue virus infection of cultured ovine and bovine pulmonary artery and lung microvascular endothelial cells. J. Gen. Virol. 82, 787-794.

DeMaula, C. D., Leutenegger, C. M., Bonneau, K. R. \& Maclachlan, N. J., 2002a. The role of endothelial cell-derived inflammatory and vasoactive mediators in the pathogenesis of bluetongue. Virology 296, 330-337.

DeMaula, C. D., Leutenegger, C. M., Jutila, M. A. \& Maclachlan, N. J., 2002b. Bluetongue virus-induced activation of primary bovine lung microvascular endothelial cells. Vet. Immunol. Immunopathol. 86, 147-157.

Desmecht, D., Bergh, R. V., Sartelet, A., Leclerc, M., Mignot, C., Misse, F., Sudraud, C., Berthemin, S., Jolly, S., Mousset, B., Linden, A., Coignoul, F. \& Cassart, D., 2008. Evidence for transplacental transmission of the current wild-type strain of bluetongue virus serotype 8 in cattle. Vet. Rec. 163, 50-52.

Drew, C. P., Gardner, I. A., Mayo, C. E., Matsuo, E., Roy, P. \& Maclachlan, N. J., 2010. Bluetongue virus infection alters the impedance of monolayers of bovine endothelial cells as a result of cell death. Vet. Immunol. Immunopathol. 2010, 136, 108-115.

Du Toit, R. M., 1944. The transmission of bluetongue and horsesickness by Culicoides. Onderstepoort J. Vet. Sci. Anim. Ind., 7-16.

Eaton, B. T., Hyatt, A. D. \& White, J. R., 1988. Localization of the nonstructural protein NS1 in bluetongue virus-infected cells and its presence in virus particles. Virology $163,527-537$. 
El Hussein, A., Ramig, R. F., Holbrook, F. R. \&, Beaty, B. J., 1989. Asynchronous mixed infection of Culicoides variipennis with bluetongue virus serotypes 10 and 17 . J. Gen. Virol. 70, 3355-3362.

Erasmus, B. J., 1975a. Bluetongue in sheep and goats. Aust. Vet. J. 51, 165-170.

Erasmus, B. J., 1975b. The control of bluetongue in an enzootic situation. Aust. Vet. J. $51,209-210$.

Erasmus, B. J., 1990. Bluetongue virus. In: Z.Dinter and B.Morein (Ed.), Virus Infections of Ruminants. Elsevier Science Publishers, New York, pp. 227-237.

Eschbaumer, M., Hoffmann, B., Moss, A., Savini, G., Leone, A., Konig, P., Zemke, J., Conraths, F. \& Beer, M., 2009. Emergence of bluetongue virus serotype 6 in Europe-German field data and experimental infection of cattle. Vet. Microbiol, doi:10.1016/j.vetmic.2009.11.040

Firth, A. E., 2008. Bioinformatic analysis suggests that the Orbivirus VP6 cistron encodes an overlapping gene. Virol. J. 5, 48.

Flanagan, M. \& Johnson, S. J., 1995. The effects of vaccination of Merino ewes with an attenuated Australian bluetongue virus serotype 23 at different stages of gestation. Aust. Vet. J. 72, 455-457.

Forzan, M., Marsh, M. \& Roy, P., 2007. Bluetongue virus entry into cells. J. Virol. 81, 4819-4827.

Forzan, M., Wirblich, C. \& Roy, P., 2004. A capsid protein of nonenveloped Bluetongue virus exhibits membrane fusion activity. Proc. Natl. Acad. Sci. U. S. A. 101, 21002105.

Fu, H., 1995. Mechanisms controlling the infection of Culicoides biting midges with bluetongue virus. PhD Thesis, University of Hertfordshire, p.p 154.

Fu, H., Leake, C. J. \& Mertens, P. P., Mellor, P. S., 1999. The barriers to bluetongue virus infection, dissemination and transmission in the vector, Culicoides variipennis (Diptera: Ceratopogonidae). Arch. Virol. 144, 747-761.

Gambles, R. M., 1949. Bluetongue of sheep in Cyprus. J. Comp. Pathol 59, 176-190.

Gerry, A. C., Mullens, B. A., Maclachlan, N. J. \& Mecham, J. O., 2001. Seasonal transmission of bluetongue virus by Culicoides sonorensis (Diptera:

Ceratopogonidae) at a southern California dairy and evaluation of vectorial capacity as a predictor of bluetongue virus transmission. J. Med. Entomol. 38, 197-209. 
Gibbs, E. P. \& Greiner, E.C., 1994. The epidemiology of bluetongue. Comp Immunol. Microbiol. Infect. Dis. 17, 207-220.

Gould, A. R., 1987. The complete nucleotide sequence of bluetongue virus serotype 1 RNA3 and a comparison with other geographic serotypes from Australia, South Africa and the United States of America, and with other orbivirus isolates. Virus Res. 7, 169-183.

Gould, A. R. \& Eaton, B. T., 1990. The amino acid sequence of the outer coat protein VP2 of neutralizing monoclonal antibody-resistant, virulent and attenuated bluetongue viruses. Virus Res. 17, 161-172.

Gould, A.R. \& Hyatt, A.D., 1994. The orbivirus genus. Diversity, structure, replication and phylogenetic relationships. Comp Immunol. Microbiol. Infect. Dis. 17, 163188.

Gould, A. R. \& Pritchard, L. I., 1990. Relationships amongst bluetongue viruses revealed by comparisons of capsid and outer coat protein nucleotide sequences. Virus Res. 17, 31-52.

Grimes, J. M., Burroughs, J. N., Gouet, P., Diprose, J. M., Malby, R., Zientara, S., Mertens, P. P. \& Stuart, D.I., 1998. The atomic structure of the bluetongue virus core. Nature 395, 470-478.

Guirakhoo, F., Catalan, J. A. \& Monath, T. P., 1995. Adaptation of bluetongue virus in mosquito cells results in overexpression of NS3 proteins and release of virus particles. Arch. Virol. 140, 967-974.

Han, Z. \& Harty, R. N., 2004. The NS3 protein of bluetongue virus exhibits viroporin-like properties. J. Biol. Chem. 279, $43092-43097$.

Hassan, S. H., Wirblich, C., Forzan, M. \& Roy, P., 2001. Expression and functional characterization of bluetongue virus VP5 protein: role in cellular permeabilization. J. Virol. 75, 8356-8367.

Hassan, S. S. \& Roy, P., 1999. Expression and functional characterization of bluetongue virus VP2 protein: role in cell entry. J. Virol. 73, 9832-9842.

He, C. Q., Ding, N. Z., He, M., Li, S. N., Wang, X. M., He, H. B., Liu, X. F. \& Guo, H. S., 2010. Intragenic recombination as a mechanism of genetic diversity in bluetongue virus. J. Virol 84, 11487-11495.

Hewat, E. A., Booth, T. F. \& Roy, P., 1992. Structure of bluetongue virus particles by cryoelectron microscopy. J. Struct. Biol. 109, 61-69. 
Howell, P. G., Kumm, N. A. \& Botha, M. J., 1970. The application of improved techniques to the identification of strains of bluetongue virus. Onderstepoort $\mathrm{J}$. Vet. Res. 37, 59-66.

Huismans, H. \& Els, H. J., 1979. Characterization of the tubules associated with the replication of three different orbiviruses. Virology 92, 397-406.

Huismans, H. \& Erasmus, B. J., 1981. Identification of the serotype-specific and groupspecific antigens of bluetongue virus. Onderstepoort J. Vet. Res. 48, 51-58.

Huismans, H., Van Dijk, A. A. \& Els, H. J., 1987. Uncoating of parental bluetongue virus to core and subcore particles in infected L cells. Virology 157, 180-188.

Hyatt, A. D., Gould, A. R., Coupar, B. \& Eaton, B. T., 1991. Localization of the nonstructural protein NS3 in bluetongue virus-infected cells. J. Gen. Virol. 72, 22632267.

Hyatt, A. D., Zhao, Y. \& Roy, P., 1993. Release of bluetongue virus-like particles from insect cells is mediated by BTV nonstructural protein NS3/NS3A. Virology 193, 592-603.

Jones, R. H. \& Foster, N. M., 1974. Oral infection of Culicoides variipennis with bluetongue virus: development of susceptible and resistant lines from a colony population. J. Med. Entomol. 11, 316-323.

Jones, R. H. \& Foster, N. M., 1978. Heterogeneity of Culicoides variipennis field populations to oral infection with bluetongue virus. Am. J. Trop. Med. Hyg. 27, 178-183.

Kahlon, J., Sugiyama, K. \& Roy, P., 1983. Molecular basis of bluetongue virus neutralization. J. Virol. 48, 627-632.

Kirkland, P. \& Hawkes, R.A., 2004. A comparison of laboratory and 'wild' strains of bluetongue virus - is there any difference and does it matter? Vet. Ital. 40, 448455.

Kirkland, P.D., 2004. Bluetongue viruses, vectors and surveillance in Australia - the current situation and unique features. Vet. Ital. 40, 2004-47.

Kirkwood, C. D., 2010. Genetic and antigenic diversity of human rotaviruses: potential impact on vaccination programs. J. Infect. Dis. 202, S43-S48.

Leemans, J., Raes, M., Vanbinst, T., De, C.K., Saegerman, C. \& Kirschvink, N., 2011. Viral RNA load in semen from bluetongue serotype 8-infected rams: Relationship with sperm quality. Vet. J. Epub ahead of print, http://dx.doi.org/10.1016/j.tvjl.2011.06.028: 06 June, 2012. 
Lewis, S. A. \& Grubman, M. J., 1990. Bluetongue virus: surface exposure of VP7. Virus Res. 16, 17-26.

Luedke, A.J. \& Anakwenze, E.I., 1972. Bluetongue virus in goats. Am. J. Vet. Res. 33, 1739-1745.

Lymperopoulos, K., Noad, R., Tosi, S., Nethisinghe, S., Brierley, I. \& Roy, P., 2006. Specific binding of Bluetongue virus NS2 to different viral plus-strand RNAs. Virology 353, 17-26.

Maan, N. S., Maan, S., Guimera, M., Nomikou, K., Morecroft, E., Pullinger, G., Belaganahalli, M. N. \& Mertens, P. P., 2012a. The genome sequence of a reassortant bluetongue virus serotype 3 from India. J Virol 86, 6375-6376.

Maan, N. S., Maan, S., Nomikou, K., Guimera, M., Pullinger, G., Singh, K. P., Belaganahalli, M. N. \& Mertens, P. P., 2012b. The Genome Sequence of Bluetongue Virus Type 2 from India: Evidence for Reassortment between Eastern and Western Topotype Field Strains. J Virol 86, 5967-5968.

Maan, S., Maan, N. S., Nomikou, K., Batten, C., Antony, F., Belaganahalli, M. N., Samy, A. M., Reda, A. A., Al-Rashid, S. A., El, B. M., Oura, C. A. \& Mertens, P. P., 2011. Novel bluetongue virus serotype from Kuwait. Emerg. Infect. Dis. 17, 886889.

Maan, S., Maan, N. S., Ross-smith, N., Batten, C. A., Shaw, A. E., Anthony, S. J., Samuel, A. R., Darpel, K. E., Veronesi, E., Oura, C. A., Singh, K. P., Nomikou, K., Potgieter, A. C., Attoui, H., Van Rooij, E., Van Rijn, P., De Clercq, K., Vandenbussche, F., Zientara, S., Breard, E., Sailleau, C., Beer, M., Hoffman, B., Mellor, P. S. \& Mertens, P. P., 2008. Sequence analysis of bluetongue virus serotype 8 from the Netherlands 2006 and comparison to other European strains. Virology 377, 308-318.

Maan, S., Maan, N. S., Samuel, A. R., Rao, S., Attoui, H. \& Mertens, P. P., 2007a. Analysis and phylogenetic comparisons of full-length VP2 genes of the 24 bluetongue virus serotypes. J. Gen. Virol. 88, 621-630.

Maan, S., Maan, N. S., Van Rijn, P. A., Van Gennip, R. G., Sanders, A., Wright, I. M., Batten, C., Hoffmann, B., Eschbaumer, M., Oura, C. A., Potgieter, A. C., Nomikou, K. \& Mertens, P. P., 2010. Full genome characterisation of bluetongue virus serotype 6 from the Netherlands 2008 and comparison to other field and vaccine strains. PLoS. One. 5, e10323.

Maan, S., Rao, S., Maan, N. S., Anthony, S. J., Attoui, H., Samuel, A. R. \& Mertens, P. P., 2007b. Rapid cDNA synthesis and sequencing techniques for the genetic study of bluetongue and other dsRNA viruses. J. Virol. Methods 143, 132-139. 
Maartens, L.H., 2010. Tissue tropism of African Horsesickness virus in the chicken embryo, demonstrated with the avidin-biotin complex immunoperoxidase method. In. M.Sc thesis: University of Pretoria, South Africa.

Maclachlan, N. J., Crafford, J. E., Vernau, W., Gardner, I. A., Goddard, A., Guthrie, A. J. \& Venter, E. H., 2008. Experimental reproduction of severe bluetongue in sheep. Vet. Pathol. 45, 310-315.

Mahrt, C.R. \& Osburn, B.I., 1986. Experimental bluetongue virus infection of sheep; effect of vaccination: pathologic, immunofluorescent, and ultrastructural studies. Am. J. Vet. Res. 47, 1198-1203.

Martinez-Costas, J., Sutton, G., Ramadevi, N. \& Roy, P., 1998. Guanylyltransferase and RNA 5'-triphosphatase activities of the purified expressed VP4 protein of bluetongue virus. J. Mol. Biol. 280, 859-866.

Mecham, J. O. \& Johnson, D. J., 2005. Persistence of bluetongue virus serotype 2 (BTV-2) in the southeast United States. Virus Res. 113, 116-122.

Meiring, T. L., Huismans, H. \& Van Staden, V., 2009. Genome segment reassortment identifies non-structural protein NS3 as a key protein in African horsesickness virus release and alteration of membrane permeability. Arch. Virol. 154, 263-271.

Meiswinkel, R., Baldet, T., De Deken. R., Takken, W., Delecolle, J.C. \& Mellor, P.S., 2008. The 2006 outbreak of bluetongue in northern Europe--the entomological perspective. Prev. Vet. Med. 87, 55-63.

Mellor, P. S., Boorman, J. \& Baylis, M., 2000. Cullicoides biting midges: Their role as arbovirus vectors. Annu. Rev. Entomol. 45, 307-340.

Menzies, F. D., McCullough, S. J., McKeown, I. M., Forster, J. L., Jess, S., Batten, C., Murchie, A. K., Gloster, J., Fallows, J. G., Pelgrim, W., Mellor, P. S. \& Oura, C. A., 2008. Evidence for transplacental and contact transmission of bluetongue virus in cattle. Vet. Rec. 163, 203-209.

Mertens, P. P., Burroughs, J. N., Walton, A., Wellby, M. P., Fu, H., O'Hara, R. S., Brookes, S. M. \& Mellor, P.S., 1996. Enhanced infectivity of modified bluetongue virus particles for two insect cell lines and for two Culicoides vector species. Virology 217, 582-593.

Mertens, P. P., Pedley, S., Cowley, J., Burroughs, J. N., Corteyn, A. H., Jeggo, M. H., Jennings, D. M. \& Gorman, B. M., 1989. Analysis of the roles of bluetongue virus outer capsid proteins VP2 and VP5 in determination of virus serotype. Virology $170,561-565$. 
Modrof, J., Lymperopoulos, K. \& Roy, P., 2005. Phosphorylation of bluetongue virus nonstructural protein 2 is essential for formation of viral inclusion bodies. J. Virol. 79, 10023-10031.

Nason, E. L., Rothagel, R., Mukherjee, S. K., Kar, A. K., Forzan, M., Prasad, B. V. \& Roy, P., 2004. Interactions between the inner and outer capsids of bluetongue virus. J. Virol. 78, 8059-8067.

Nevill, E. M., Erasmus, B. J. \& Venter, G. J., 1992. A six-year survey of viruses associated with Culicoides biting midges throughout South Africa (Diptera: Ceratopogonidae). In: Walton, T.E., Osburn, B.I. (Eds.), Proc. Second International Symposium. CRC Press, Boca, Raton, pp. 314-319.

O'Hara, R. S., Meyer, A. J., Burroughs, J. N., Pullen, L., Martin, L. A. \& Mertens, P. P., 1998. Development of a mouse model system, coding assignments and identification of the genome segments controlling virulence of African horse sickness virus serotypes 3 and 8. Arch. Virol. Suppl 14, 259-279.

Oberst, R. D., Stott, J. L., Blanchard-Channell, M. \& Osburn, B. I., 1987. Genetic reassortment of bluetongue virus serotype 11 strains in the bovine. Vet. Microbiol. 15, 11-18.

OIE, 2004. OIE Manual for Diagnostic Tests and Vaccines.

Osburn, B.I., 1994. The impact of bluetongue virus on reproduction. Comp Immunol. Microbiol. Infect. Dis. 17, 189-196.

Owens, R. J., Limn, C. \& Roy, P., 2004. Role of an arbovirus nonstructural protein in cellular pathogenesis and virus release. J. Virol. 78, 6649-6656.

Parsonson, I. M., Della-Porta, A. J., McPhee, D. A., Cybinski, D. H., Squire, K. R. \& Uren, M. F., 1987. Bluetongue virus serotype 20: experimental infection of pregnant heifers. Aust. Vet. J. 64, 14-17.

Pierce, C. M., Balasuriya, U. B. \& Maclachlan, N. J., 1998. Phylogenetic analysis of the S10 gene of field and laboratory strains of bluetongue virus from the United States. Virus Res. 55, 15-27.

Potgieter, A. C., Steele, A. D. \& Van Dijk, A. A., 2002. Cloning of complete genome sets of six dsRNA viruses using an improved cloning method for large dsRNA genes. J. Gen. Virol. 83, 2215-2223.

Purse, B. V., Mellor, P. S., Rogers, D. J., Samuel, A. R., Mertens, P. P. \& Baylis, M., 2005. Climate change and the recent emergence of bluetongue in Europe. Nat. Rev. Microbiol. 3, 171-181. 
Ramadevi, N., Burroughs, N. J., Mertens, P. P., Jones, I. M. \& Roy, P., 1998. Capping and methylation of mRNA by purified recombinant VP4 protein of bluetongue virus. Proc. Natl. Acad. Sci. U. S. A. 95, 13537-13542.

Ramig, R. F., Garrison, C., Chen, D. \& Bell-Robinson, D., 1989. Analysis of reassortment and superinfection during mixed infection of Vero cells with bluetongue virus serotypes 10 and 17. J. Gen. Virol. 70, 2595-2603.

Ratinier, M., Caporale, M., Golder, M., Franzoni, G., Allan, K., Nunes, S. F., Armezzani, A., Bayoumy, A., Rixon, F., Shaw, A. \& Palmarini, M., 2011. Identification and characterization of a novel non-structural protein of bluetongue virus. PLoS Pathog. 7, e1002477.

Riegler, L., 2002. Variation in African Horse Sickness Virus And Its Effect On The Vector Competence Of Culicoides Biting Midges. In. University of Surrey, http://epubs.surrey.ac.uk/843/.

Saegerman, C., Berkvens, D. \& Mellor, P. S., 2008. Bluetongue Epidemiology in the European Union. Emerg. Infect. Dis. 14, 539-544.

Saegerman, C., Bolkaerts, B., Baricalla, C., Raes, M., Wiggers, L., De, L., I, Vandenbussche, F., Zimmer, J.Y., Haubruge, E., Cassart, D., De Clercq, K. \& Kirschvink, N., 2010. The impact of naturally-occurring, trans-placental bluetongue virus serotype-8 infection on reproductive performance in sheep. Vet. J. $187,72-80$.

Samal, S. K., El-Hussein, A., Holbrook, F. R., Beaty, B. J. \& Ramig, R. F., 1987a. Mixed infection of Culicoides variipennis with bluetongue virus serotypes 10 and 17: evidence for high frequency reassortment in the vector. J. Gen. Virol. 68, 23192329.

Samal, S. K., Livingston, C. W., Jr., McConnell, S. \& Ramig, R.F., 1987b. Analysis of mixed infection of sheep with bluetongue virus serotypes 10 and 17: evidence for genetic reassortment in the vertebrate host. J. Virol. 61, 1086-1091.

Santman-Berends, I. M., Van Wuijckhuise, L., Vellema, P. \& Van Rijn, P. A., 2010. Vertical transmission of bluetongue virus serotype 8 virus in Dutch dairy herds in 2007. Vet Microbiol. 141, 31-35.

Schultz, G. \& Delay, P.D., 1955. Losses in newborn lambs associated with bluetongue vaccination of pregnant ewes. J. Am. Vet. Med. Assoc. 127, 224-226.

Spreull, J., 1905. Malarial catarrhal fever (bluetongue) of sheep in South Africa. J. Comp. Pathol. Therapeut. 18, 321-337. 
Stauber, N., Martinez-Costas, J., Sutton, G., Monastyrskaya, K. \& Roy, P., 1997. Bluetongue virus VP6 protein binds ATP and exhibits an RNA-dependent ATPase function and a helicase activity that catalyze the unwinding of doublestranded RNA substrates. J. Virol. 71, 7220-7226.

Stott, J. L., Oberst, R. D., Channell, M. B. \& Osburn, B. I., 1987. Genome segment reassortment between two serotypes of bluetongue virus in a natural host. $J$. Virol. 61, 2670-2674.

Stott, J. L., Osburn, B. I. \& Barber, T. L., 1982. Recovery of dual serotypes of bluetongue virus from infected sheep and cattle. Vet. Microbiol. 7, 197-207.

Stott, J. L., Osburn, B. I., Bushnell, R., Loomis, E. C. \& Squire, K. R., 1985. Epizootiological study of bluetongue virus infection in California livestock: an overview. Prog. Clin. Biol. Res. 178, 571-582.

Sugiyama, K., Bishop, D. H. \& Roy, P., 1982. Analysis of the genomes of bluetongue viruses recovered from different states of the United States and at different times. Am. J. Epidemiol. 115, 332-347.

Tabachnick, W., 2004. Culicoides and the global epidemiology of bluetongue virus infection. Vet. Ital. 40, 145-150.

Tabachnick, W. J., 1991. Genetic control of oral susceptibility to infection of Culicoides variipennis with bluetongue virus. Am. J. Trop. Med. Hyg. 45, 666-671.

Tan, B. H., Nason, E., Staeuber, N., Jiang, W., Monastryrskaya, K. \& Roy, P., 2001. RGD tripeptide of bluetongue virus VP7 protein is responsible for core attachment to Culicoides cells. J. Virol. 75, 3937-3947.

Urakawa, T., Ritter, D. G. \& Roy, P., 1989. Expression of largest RNA segment and synthesis of VP1 protein of bluetongue virus in insect cells by recombinant baculovirus: association of VP1 protein with RNA polymerase activity. Nucleic Acids Res. 17, 7395-7401.

Urakawa, T. \& Roy, P., 1988. Bluetongue virus tubules made in insect cells by recombinant baculoviruses: expression of the NS1 gene of bluetongue virus serotype 10. J. Virol. 62, 3919-3927.

Van der Sluijs, M., Timmermans, M., Moulin, V., Noordegraaf, C. V., Vrijenhoek, M., Debyser, I., De Smit, A. J. \& Moormann, R., 2011. Transplacental transmission of Bluetongue virus serotype 8 in ewes in early and mid gestation. Vet. Microbiol $149,113-125$.

Van Dijk, A. A. \& Huismans, H., 1988. In vitro transcription and translation of bluetongue virus mRNA. J. Gen. Virol. 69, 573-581. 
Van Gennip, R. G., Van de Water, S. G., Potgieter, C. A., Wright, I., Veldman, D. \& Van Rijn, P. A., 2012. Rescue of recent virulent and avirulent field strains of bluetongue virus by reverse genetics. PLoS One. 7, e30540.

Van Gennip, R. G., Veldman, D., Van de Water, S. G. \& Van Rijn, P. A., 2010. - Genetic modification of bluetongue virus by uptake of "synthetic" genome segments. Virol. J. 7, 261.

Van Rijn, P. A., Geurts, Y., Van der Spek, A. N., Veldman, D. \& Van Gennip, R. G., 2012. Bluetongue virus serotype 6 in Europe in 2008-Emergence and disappearance of an unexpected non-virulent BTV. Vet. Microbiol. Epub ahead of print, doi:10.1016/j.vetmic.2012.01.022

Vanbinst, T., Vandenbussche, F., Dernelle, E. \& De Clercq, K., 2010. A duplex real-time RT-PCR for the detection of bluetongue virus in bovine semen. J. Virol. Methods $169,162-168$.

Venter, G. J., Mellor, P. S. \& Paweska, J. T., 2006. Oral susceptibility of South African stock-associated Culicoides species to bluetongue virus. Med. Vet. Entomol. 20, 329-334.

Venter, G. J. \& Paweska, J. T., 2007. Virus recovery rates for wild-type and liveattenuated vaccine strains of African horse sickness virus serotype 7 in orally infected South African Culicoides species. Med. Vet. Entomol. 21, 377-383.

Venter, G. J., Paweska, J. T., Van Dijk, A. A., Mellor, P. S. \& Tabachnick, W. J., 1998. Vector competence of Culicoides bolitinos and C. imicola for South African bluetongue virus serotypes 1, 3 and 4. Med. Vet. Entomol. 12, 378-385.

Vercauteren, G., Miry, C., Vandenbussche, F., Ducatelle, R., Van der Heyden, S., Vandemeulebroucke, E., De Leeuw, I., Deprez, P., Chiers, K. \& De Clerqc, K., 2008. Bluetongue virus serotype 8 -associated congenital hydranencephaly in calves. Transbound. Emerg. Dis. 55, 293-298.

Veronesi, E., Venter, G. J., Labuschagne, K., Mellor, P. S. \& Carpenter, S., 2009. Lifehistory parameters of Culicoides (Avaritia) imicola Kieffer in the laboratory at different rearing temperatures. Vet. Parasitol. 163, 370-373.

Veronesi, E., Hamblin, C. \& Mellor, P. S., 2005. Live attenuated bluetongue vaccine viruses in Dorset Poll sheep, before and after passage in vector midges (Diptera: Ceratopogonidae). Vaccine 23, 5509-5516.

Verwoerd, D. W., 2009. History of Bluetongue research at Onderstepoort. Onderstepoort J. Vet. Res 76, 99-102. 
Verwoerd, D. W., Els, H. J., De Villiers, E. M. \& Huismans, H., 1972. Structure of the bluetongue virus capsid. J. Virol. 10, 783-794.

Verwoerd D. W. \& Erasmus, B. J., 2004. Bluetongue. In Infectious Diseases of Livestock, 2nd edition. Edited by Coetzer J.A.W and Tustin RC. Cape Town, South Africa: Oxford University Press; pp. 1201-1220.

Verwoerd, D. W., Louw, H. \& Oellermann, R. A., 1970. Characterization of bluetongue virus ribonucleic acid. J. Virol. 5, 1-7.

Vosdingh, R. A., Trainer, D. O. \& Easterday, B. C., 1968. Experimental bluetongue disease in white-tailed deer. Can. J. Comp Med. Vet. Sci. 32, 382-387.

Waldvogel, A. S., Anderson, C. A., Higgins, R. J. \& Osburn, B. I., 1987. Neurovirulence of the UC-2 and UC-8 strains of bluetongue virus serotype 11 in newborn mice. Vet. Pathol. 24, 404-410.

Waldvogel, A. S., Anderson, G. A., Phillips, D. L. \& Osburn, B. I., 1992a. Association of virulent and avirulent strains of bluetongue virus serotype 11 with premature births of late-term bovine fetuses. J. Comp Pathol. 106, 333-340.

Waldvogel, A. S., Anderson, G. A., Phillips, D. L. \& Osburn, B. I., 1992b. Infection of bovine fetuses at 120 days' gestation with virulent and avirulent strains of bluetongue virus serotype 11. Comp Immunol. Microbiol. Infect. Dis. 15, 53-63.

Waldvogel, A. S., Stott, J. L., Squire, K. R. \& Osburn, B. I., 1986. Strain-dependent virulence characteristics of bluetongue virus serotype 11. J. Gen. Virol. 67, 765769.

Walton, T. E., 1992. Attenuated and inactivated orbiviral vaccines. In: Bluetongue and related Orbiviruses. Alan R. Liss, New York, pp. 851-855.

Wenske, E. A., Chanock, S. J., Krata, L.\& Fields, B. N., 1985. Genetic Reassortment of Mammalian Reoviruses in Mice. J. Virol. 56, 613-616.

White, D. M., Blair, C. D. \& Beaty, B. J., 2006. Molecular epidemiology of bluetongue virus in northern Colorado. Virus Res. 118, 39-45.

Wilson, A. \& Mellor, P.S., 2009. Bluetongue in Europe: past, present and future. Phil. Trans. R. Soc. B 364, 2669-2681.

Wilson, W. C., Bernard, K. A., Israel, B. A. \& Mecham, J. O., 2008. Bluetongue virus serotype 17 sequence variation associated with neutralization. DNA Seq. 19, 237-240. 
Wilson, W. C., Ma, H. C., Venter, E. H., Van Djik, A. A., Seal, B. S., Mecham, J.O. \& 2000. Phylogenetic relationships of bluetongue viruses based on gene S7. Virus Res. 67, 141-151.

Wirblich, C., Bhattacharya, B. \& Roy, P., 2006. Nonstructural protein 3 of bluetongue virus assists virus release by recruiting ESCRT-I protein Tsg101. J. Virol. 80, 460-473.

Wittmann, E. J., Mellor, P. S. \& Baylis, M., 2002. Effect of temperature on the transmission of orbiviruses by the biting midge, Culicoides sonorensis. Med. Vet. Entomol. 16, 147-156.

Wu, X., Chen, S. Y., Iwata, H., Compans, R. W. \& Roy, P., 1992. Multiple glycoproteins synthesized by the smallest RNA segment (S10) of bluetongue virus. J. Virol. 66, 7104-7112.

Xu, G., Wilson, W., Mecham, J., Murphy, K., Zhou, E.M., Tabachnick, W., 1997. VP7: an attachment protein of bluetongue virus for cellular receptors in Culicoides variipennis. J. Gen. Virol. 78, 1617-1623.

Zhang, X., Boyce, M., Bhattacharya, B., Zhang, X., Schein, S., Roy, P. \& Zhou, Z. H., 2010. Bluetongue virus coat protein VP2 contains sialic acid-binding domains, and VP5 resembles enveloped virus fusion proteins. Proc. Natl. Acad. Sci. U.S.A. $107,6292-6297$. 